Pécsi Tudományegyetem, Fogorvostudományi Szak, Fogpótlástani Tanszék, Pécs* Szegedi Tudományegyetem, Fogorvostudományi Kar, Szeged**

Semmelweis Egyetem, Fogorvostudományi Kar, Fogpótlástani Klinika, Budapest ${ }^{\star \star *}$

Debreceni Egyetem, Fogorvostudományi Kar, Bioanyagtani és Fogpótlástani nem önálló Tanszék, Debrecen***

\title{
A foghiányok osztályozásának lehetőségei régen és ma
}

\author{
DR. MARADA GYULA*, DR. BARÁTH ZOLTÁN**, DR. BORBÉLY JUDIT***, DR. HERMANN PÉTER ${ }^{\star \star *}$ \\ DR. RADICS TÜNDE ${ }^{\star * \star}$, DR. RADNAI MÁRTA ${ }^{\star *}$, DR. HEGEDÜS CSABA ${ }^{\star \star \star *}$
}

\begin{abstract}
A foghiányok különböző osztályozását a protetikai ellátás megkönnyítésére, egységesítésére fejlesztették ki. Alapkoncepcióik jól tükrözik az adott korszak legkorszerübb anyagtani és ellátási irányelveit. A különböző osztályozási rendszerek számos előnyös tulajdonsággal rendelkeztek, de egyik sem tudta a velük szemben támasztott követelményeket maradéktalanul teljesíteni.

Az elsők között publikált osztályozási forma az aktuális szemléletnek megfelelően a részleges kivehető fogpótlásokkal történő ellátáson alapult. Nem sokkal később Edward Kennedy megalkotta a mai napig nemzetközileg is legáltalánosabban használt osztályozási rendszerét, amelynek alapja az egyes foghiányok előfordulási gyakorisága. Hazai körülményekre adaptált, elsősorban gyakorlatorientált sémát dolgozott ki több kiváló fogorvos, akik közül Lőrinczy és Földvári, valamint Fábián és Fejérdy munkásságát kell kiemelni.

Az eddigi rendszerek hiányosságait mérlegelve az Amerikai Fogpótlástani Társaság merőben új rendszert dolgozott ki. Cél, hogy terápiás támpontot adjon a gyakorló fogorvos számára a legkorszerúbb ellátási elveknek megfelelóen. Ellátásuk bonyolultsága, komplexitása szerint történik az osztályba sorolás a gerinc karakterisztikája, a fogatlan állcsont, a pillérfogak és az okklúzió figyelembevételével.
\end{abstract}

Kulcsszavak: foghiány, osztályozás,

\section{Bevezetés}

A foghiányos állapotok gyógyításával egyidős az a törekvés, hogy a különböző foghiányokat egységbe foglaljuk, csoportosítsuk. Így kis túlzással azt is mondhatjuk, hogy a fogpótlástan története jól jellemezhető a különböző foghiányos állapotokra felállított osztályozási rendszerek áttekintésével.

Az esetek többségében már egyetlen fog elvesztésével megszúnik a fogazatnak a kontaktpont rendszerrel és az okklúziós érintkezésekkel fenntartott funkcionális egysége. A hiányt határoló fogak egymás felé dőlnek, vándorolnak és ha antagonista foghiány is fennáll, a fogívből kiemelkednek. Így minden foghiány többletterhelést és okklúziós anomáliát okoz, ami, ha hosszú ideig fennáll, kényszermozgások kialakulásához és a parodontium károsodásához vezethet. Ezek elkerülésének céljából igen fontos a protetikai rehabilitáció. A fogpótlás módjáról már megoszlanak a vélemények.

A kérdésekre adandó választ befolyásolja a protetikai szemlélet és az adott korszak fogtechnikai technológiájának fejlettsége.

A részleges foghiányok pótlásának tervezését elsősorban a maradék fogak száma és elhelyezkedése határozza meg. Az összes többi tényező tulajdonképpen csak befolyásolja, módosítja az előbbiek által meghatározott lehetőségeket.

A sokféle befolyásoló tényező áttekintése és figyelembevétele csak úgy lehetséges, ha valamilyen rendszerbe foglaljuk őket. Részben ezt a célt szolgálja a foghiányok különböző osztályozási rendszere, melynek széles skáláját dolgozták ki az elmúlt évtizedekben. Külön ki kell emelni a legáltalánosabban használt Kennedy-, Eichner-, és a hazánkban leginkább elterjedt Fábián- és Fejérdy féle protetikai osztályozási rendszereket. Célunk, hogy áttekintést adjunk a különböző osztályozási rendszerekről, fejlődésükről, alkalmazásuk gyakorlati vonatkozásairól.

\section{Az osztályozási rendszerek áttekintése}

A részleges foghiányok osztályozásának számos módját ajánlják és használják manapság. A foghiányok lehetséges variációinak száma olyan nagy, hogy megfelelő rendszerezés nélkül áttekinthetetlen. Így érthető, hogy a foghiányok rendszerezése, osztályozása régi törekvése a fogorvosoknak, és évek alatt számos kísérletet végeztek a részleges foghiányok klasszifikációjára.

Az elsők között publikálta 1920-ban osztályozási rend- 
szerét William Ernest Cummer (1879-1942). Az ő beosztása a kapcsokat összekötő vonalat veszi alapul. Ha a kapcsokat összekötő vonal mindkét oldalára jutnak protézisrészek és rágófelületek, akkor a fogmủ kétkarú emelőként müködik és funkció közben is stabil. $A$ részleges protéziseket Cummer az elhorgonyzás módja szerint négy csoportba osztja. Direkt rögzítők a kapcsok, csúsztatók; indirekt rögzítö́k a lemez támaszkodó szélei, nyúlványai, a billenésgátlók. Az elhorgonyzás tehát: 1. diagonális $x$ : 2 direkt rögzítő (kapocs), egymással diagonálisan szemben.

2. diametrikus +: 2 direkt rögzítő (kapocs), egymással diametrikusan szemben.

3. unilaterális: 2 vagy több direkt rögzítő (kapocs) egy oldalon.

4. multilaterális $\Delta$ : direkt rögzítők (kapcsok) három vagy ritkán négy, háromszögnek vagy négyszögnek megfelelö elhelyezésben.

Az előzőekből látható, hogy osztályozási rendszerének alapja a fém alaplemezű, kapoccsal elhorgonyzott, részleges kivehető fogpótlás készítése volt, ami megfelelt kora aktuális szemléletének.

Didaktikailag a következő osztályozási rendszer Edward Kennedy (1928) amerikai fogorvos nevéhez füződik. A mind a mai napig legáltalánosabban alkalmazott osztályozásának alapja az egyes foghiánytípusok előfordulásának gyakorisága volt. A hiányokat négy osztályba sorolta. I. osztályba a kétoldali, a II. osztályba az egyoldali, szabad végú foghiányok tartoznak, a III. osztályban a hiány mögött is van pillér; a IV. osztályba a frontfoghiányok tartoznak. A beosztás az I., a II. és a III. osztályon belül négy alosztályt különböztet meg a maradék fogak közötti rések száma szerint (1. ábra).

Az osztályba sorolás alkalmával ajánlatos figyelembe venni az Oliver C. Applegate által megadott szabályokat, így elkerülhetővé válnak a hibás besorolások. Ezen szabályokat az osztályozás megkezdése előtt kell alkalmazni.

Kennedy azonosította a fogatlan területeknek két különböző típusát: distálisan kiterjedő, illetve a modifikációs területeket. A hátsó régióban elhelyezkedő fogatlan gerinc a legtöbb esetben meghatározza a foghiány osztályát.

Kennedy osztályozási rendszerének sikerét az adta, hogy az egyes foghiányok előfordulási gyakorisága az évtizedek alatt keveset változott. Széleskörű elterjedésének másik alapja az, hogy független az alkalmazott fogpótlástól. Egyik nagy hátránya, hogy nem vette figyelembe - többek között - az antagonista fogazatot.

Kennedy osztályozási rendszerét továbbgondolva Max Müller és Elbrecht egymástól függetlenül készített beosztást, amelyeket egyesítve megkülönböztethetünk közbeiktatott, szabad végű és kombinációs protéziseket. Ez azt is jelenti, hogy fogpótlást javasoltak az egyes Kennedy osztályok ellátására.

Az előzőektől eltérő, sokkal inkább funkcionális szempontokat szem előtt tartó besorolás volt a Máthé féle intermaxilláris rendszer, tehát müködéses szempontokat is figyelembe vevő beosztást ajánlott: a foghi-

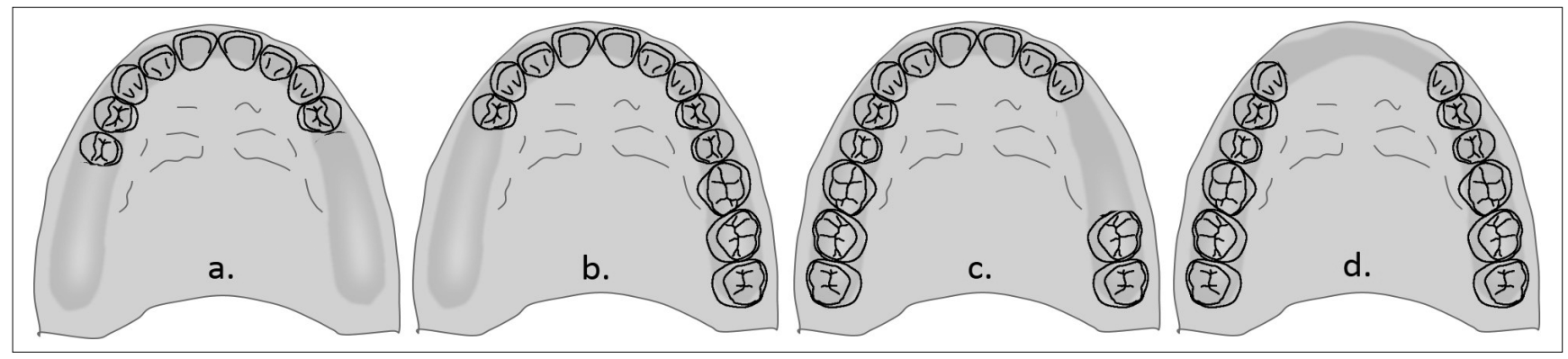

1. ábra: A Kennedy osztályozási rendszer.

a (I. osztály): distális kiterjedésű bilaterális foghiány,

b (II. osztály): unilaterális foghiány a hátsó régióban, c (III. osztály): unilaterális sorközi foghiány, d (IV. osztály): egyetlen fogatlan sorközi régió, mely metszi a középvonlat.

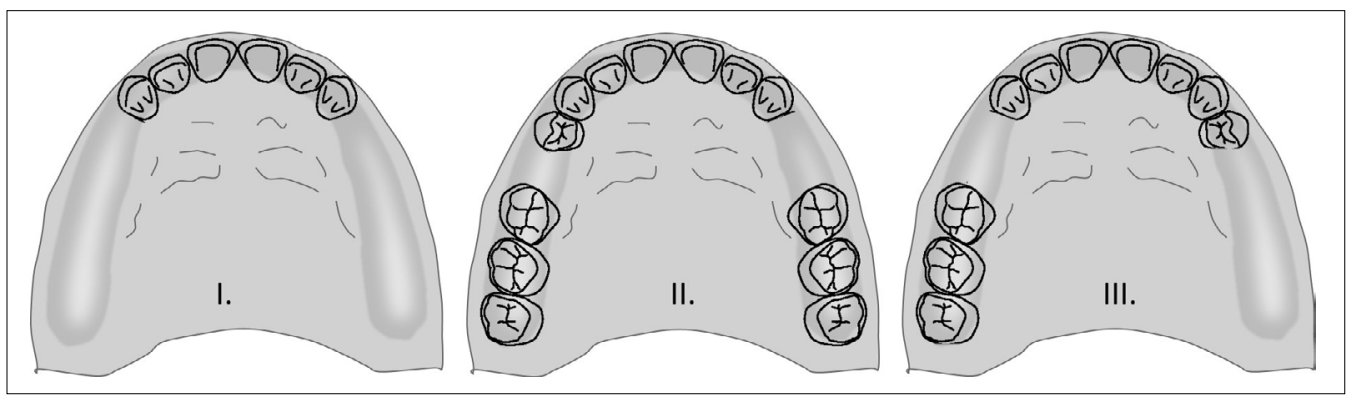

2. ábra: Wild beosztásának sémája 
ányok topográfikus eloszlása szerint megkülönböztetett találkozó, váltakozó és vegyes hiányokat.

Az öntött kapcsokkal nyert hosszú távú tapasztalatokra alapozva egyre nyilvánvalóbbá vált, hogy a részleges kivehető fogpótlás akkor lesz hosszú távon is sikeres, ha azt dentálisan is megtámasztjuk. Ezeket a megfigyeléseket alapul véve Engström a részleges fogpótlások beosztásában Elbrecht rendszerét követi és mukozálisan, valamint paradental-gingiválisan megtámasztott protéziseket különböztet meg.

Ezt követte Balters rendszere. Öt osztályba sorolja a fogpótlásokat és a rágónyomás átvitelét veszi alapul, világosan elkülönítve a megtámasztás lehetőségeit: 1. Kapocs nélküli lemezes protézis. 2 . Támfogakon kapcsokkal rögzített pótlás. 3. Fogakra támaszkodó őlőfogpótlás. 4. Részben fogakon támaszkodó, részben kapcsokkal rögzített lemezes pótlás. 5. Levehető híd és lemezes protézis kombinációja.

Bailyn (1928): Az osztályozásában az „A” illetve „P” jelzéseket alkalmazza. „A”: foghiány a front régióban (anterior), mely az első premolárisig tart. „P”: foghiány a hátsó régióban (posterior), mely a caninusoktól distálisan helyezkedik el. Összegezve: I. osztály: sorközi hiány (nem hiányzik 3 fognál több). II. osztály: sorvégi hiány (nincs distális pillér). III. osztály: sorközi hiány (több mint 3 fog hiányzik).

Így például, ha minden hátsó fog hiányzik a 3-as és 8-as fogak között, valamint az oldalsó metszők is, a klaszszifikáció Al; PIII.

Az I. osztályban dentális, míg II. és III. osztályban mukozális megtámasztás kell. Bailyn osztályozása volt az első, amelyik kihangsúlyozta a részleges foghiánynál a támfogak fontosságát.

Neurohr (1939) is osztályozta a foghiányokat a használható támfogak szerint, de a rendszer feleslegesen bonyolult volt. Neurohr osztályozása nyilvánvalóan öszszetett és bonyolult, ezért ritkán kerül alkalmazásra.

Mauk (1942) osztályozása a foghiányok számán, méretén, helyzetén, valamint a maradó fogak számán és helyzetén alapszik.

Wild (1949) beosztása egyszerü, de nyilvánvaló. Az osztályozásában három csoportot különböztet meg: I. osztály: A hiányzó, megrövidült rágópálya pótlása (Sorvégi hiány). II. osztály: A megszakított rágópálya pótlása (Sorközi hiány). III. osztály: A megrövidült és megszakított rágópálya pótlása (I. és II. osztály kombinációja).

Wild a csoportosítását azzal alapozta meg, hogy a rágófunkció a legfontosabb feladata a fogsornak, valamint a rágóeffektusért a megterhelés módja a felelős.

A későbbiek folyamán Elbrecht kidolgozott egy önálló osztályozást, melynek alapján megkülönböztet egy parodontális, parodontogingivális és tiszta mukozális megtámasztású csoportokat.

Ezekből is látható, hogy a fogpótlástan koncepciójának változásával próbáltak lépést tartani a különböző rendszerek megalkotói. Egyre inkább előtérbe került a funkcionális szemlélet és az elhorgonyzásra, illetve megtámasztásra felhasznált fogak protetikai szerepét hang- súlyozzák. A következő rendszerek is hasonló koncepción alapulnak, illetve az előzőek továbbfejlesztésével születtek. Lényeges előrelépést nem hordoztak magukban, így széleskörű elterjedésük sem következette be.

Godfrey (1951) olyan rendszert használt, amelyik a fogatlan helyek elhelyezkedésén és azok számán alapszik. Friedman (1953) bevezette az ő sajátos „A”, „B" és „C" osztályait, miszerint: „A" fronthiány, „B” nem sorvégi hátsó hiány és "C" sorvégi hiány.

Beckett (1953) és Wilson (1957) elképzelése Bailyn (1928) osztályozásán alapszik. Szerintük megfontolandók a következők:

- A pillérként használható támfogak minősége.

- A támfog okkluziós szerepe.

- Az okkluzióval való harmóniája.

- A mukóza és a visszamaradt gerinc minősége.

Az általuk meghatározott osztályok: I. osztály: Határolt gerinc: Pillérfogak alkalmasak a fogmú megtámasztására. Így a mucosát nem használjuk megtámasztásra. (Nincs mukozális megtámasztás.) II. osztály: Szabad végü (sorvégi hiány): a) Dentogingivális megtámasztás. b.) Mukozális megtámasztás. III. osztály: Határolt gerinc (sorközi hiány): Pillérfogak nem alkalmasak oly mértékben a fogmú megtámasztására, mint l. osztályban.

Carddock (1954) a következők szerint osztályozta a részleges foghiányt: I. osztály: Fogatlan gerincek mindkét végén a pillérfogakon történik a megtámasztás. II. osztály: A fogazatra eső, rágósíkra merőleges irányú kis erő́k alkalmazásakor az ellenállás teljesen a lágy szöveteké legyen. Wilson (1957) szerint a mandibula III. osztályának terápiája I. osztály szerint történjék. (Lásd Beckett féle klasszifikáció.) Míg a maxilla III. osztályának terápiája I. vagy II. osztály szerint történjék.

III. osztály: Dentális megtámasztás a gerincnek csak egyik végén valósítható meg.

Skinnert (1959) nyilvánvalóan befolyásolta Cummer és megalkotott egy olyan osztályozást ahol öt csoportot különít el. I. csoport: Sorközi hiányokat, Il. csoport: Frontfogak hiányát, III. csoport: Sorvégi hiányokat, IV. csoport: Front- és sorvégi hiányok kombinációját, valamint az V. csoport: Maradék fogak unilaterális elhelyezkedését sorolja. A legtöbb esetben karakterizálta az anatómiai és helyzeti viszonyokat a maradó fogak közt.

Austin és Lidge (1957) voltak azok, akik rámutattak arra, hogy több mint 65000-féle kombinációja lehetséges a fogak és a fogatlan gerinc egymáshoz viszonyított helyzetének. Austin és Lidge javasoltak egy osztályozást, mely leírja a hiányzó fogak helyzetét, de a leírás feleslegesen bonyolult és gyakorlati szempontból nem mutat előrelépést.

Watt (1958) véleménye szerint háromféle lehetőség van a részleges foghiány kezelésére: 1 . Teljes dentális megtámasztás, 2. Teljes mukozális megtámasztás, 3. Muko-dentális megtámasztás. A részleges foghiánynak a három módozat egyikébe kell esnie.

Mindenképpen ki kell emelni azokat a magyar fogorvosokat, akik a hazai viszonyokra próbálták adaptálni 
a nemzetközi trendeket és a fogorvosok számára gyakorlatorientált osztályozási rendszert alkottak. Salamon és Bonyhárd a részleges protézisek szisztematikájával foglalkozva a maradék fogazatra vonatkozó adatokat ordináta-tengelyre, a rágónyomás átvitelének módját pedig az abszcissza-tengelyre vonatkoztatja, és így funkcionális beosztást nyer.

Lőrinczy és Földvári beosztása a gyakorlat érdekeit tartja szem előtt, s a hazai viszonyokhoz alkalmazkodik. Legfontosabb előnye, hogy a fogpótlásra is ad javaslatot. Rágófelszíni támasztékot csak abban az esetben alkalmaznak, amikor kétoldali sorközi hiány van az őrlőfogak területén. A foghiányokat négy osztályba sorolja (3. ábra):

I. osztály: Sorközi hiány az őrlőfogak területén. Így a hiánytól mesiálisan és distálisan is van még maradó őrlőfog. Javallata a protézistervhez: dentális megtámasztású protézis; tehát főként a vertikális irányú rágónyomás a maradék fogak paradonciumára vihető át, rágófelszíni támasztékkal ellátott kapcsokkal. Ezek a horizontális irányú erőhatásokat is mérséklik. A protézis alaplemeze vázasítható, mivel a lágyrészek nem vesznek részt a rágónyomás átvitelében. Ezt az elhorgonyzási típust merevnek is nevezik, és ilyen esetben legalább négy darab támasztékos kapcsot alkalmaztak.

II. osztály: Kétoldali sorközi hiány, kombinálva egy vagy több frontfog hiányával. Javallata: szintén a dentális megtámasztású protézis, és alkalmazható a lemez vázasítása is. A támfogak megterhelése szempontjából előnyösnek tartották, ha a maradék fogakat merev egységbe foglalják.

III. osztály: Egy- vagy kétoldali sorvégi hiány. Javallata: ilyen hiányok esetében nem ajánlatos átvinni a rágónyomás vertikális irányú komponenseit a maradék fogak paradonciumára merev elhorgonyzású kapcsok alkalmazásával. Ebben az esetben ízületes erőtörők, vagy olyan protézis jöhet számításba, melynek horgonyai rágófelszíni támaszték nélküliek. A rágónyomás vertikális irányú komponenseit a lágyrészekkel fedett csontos alap viseli, így a lemezt a lehető legjobban ki kell terjeszteni, hogy minél kisebb teher jusson a nyálkahártya egységnyi felületére.

IV. osztály: Sorközi és sorvégi hiányok kombinációja. Javallata: ezen hiányok pótlására teljes mértékig érvényesek a III. osztályban leírtak.

Fiset (1973), Terkla és Laney (1963), Avant (1966), Costa (1974), valamint Osborne és Lammie (1974) Kennedy osztályozási rendszerét használták alapul, kézenfekvő változtatások nélkül, ennek ellenére nem voltak kellően kielégítők.

Körber osztályozása szintén, mint sok másik a maradék fogak elhelyezkedésén alapszik. Viszont ellentétben a többiekkel, Körber figyelembe veszi a fogpótlás megtámasztási lehetőségén kívül a maradék fogak sínezési lehetőségét is.

Mihelyt ismerté vált a Kennedy féle osztályozási mód, Wustrow kifogásolta benne, hogy nem volt figyelemmel az alsó és felső fogsor elválaszthatatlan összefüggéseire. Ezzel arra utalt, hogy egy állcsontnak a legjobb protetikai ellátása a másik állcsont ellátása nélkül nem kielégítő, mint például hiába látjuk el az adott státusszal rendelkező felső fogívet a legtökéletesebben, mégsem lesz funkcióképes, ha az antagonista fogívben teljes fogatlanság állapota áll fenn, melyet nem kezeltünk. Mindezek szem előtt tartásával Steinhardt megkülönböztetett két fő csoportot az antagonista érintkezéseket figyelembe véve. Az általa felállított csoportok egyikében álltak azon antagonista fogívek ahol a harapási magasságot természetes fogak tartották fenn, míg a másik csoportban nem volt biztosítva természetes fogakkal a harapási magasság. Ezeket szem előtt tartva megfogalmazta a következő fogászati definíciót: támasztózónák. Ha felállítjuk a két fogív antagonista érintkezéseit, szétválasztva a premolárisoknál találtakat a molárisoknál lévőkkel, így minden oldalon két támasztózónát kapunk, összesen 4 támasztózónát.

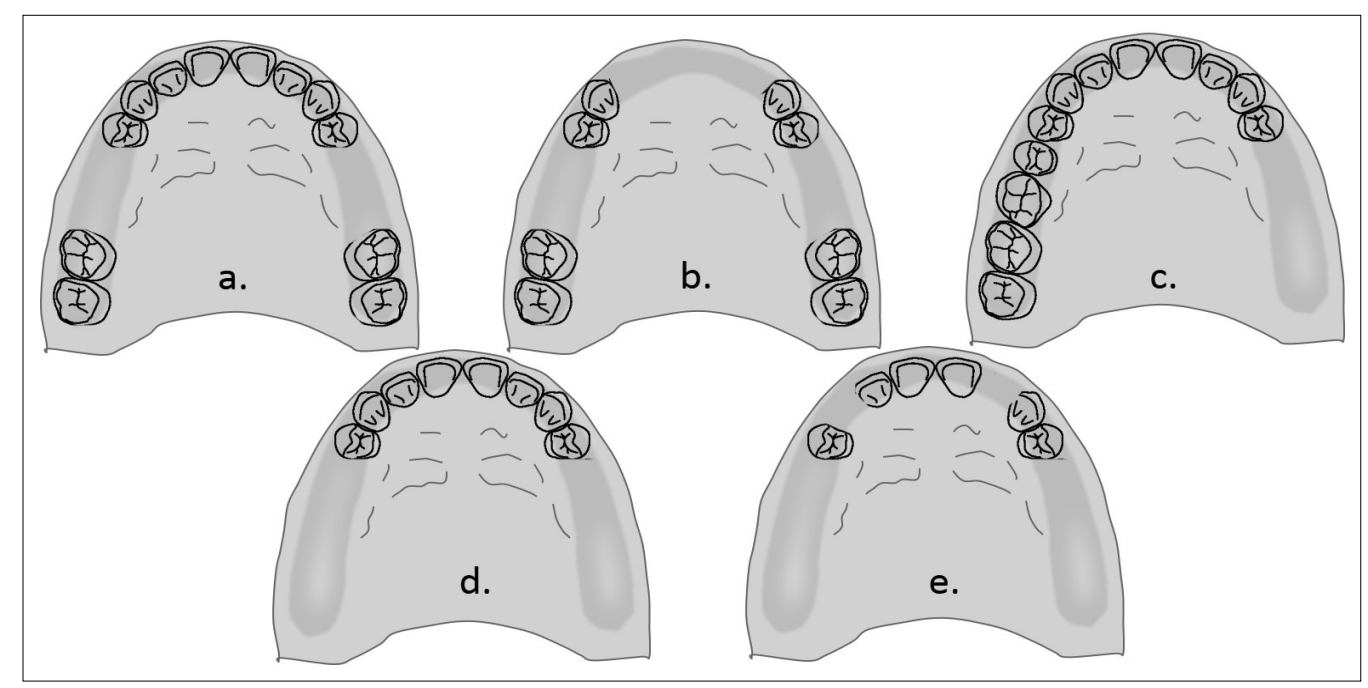

3. ábra: Lőrinczy és Földvári féle osztályozás.

a: I. osztály, b: II. osztály, c-d: III. osztály, e: IV. osztály 


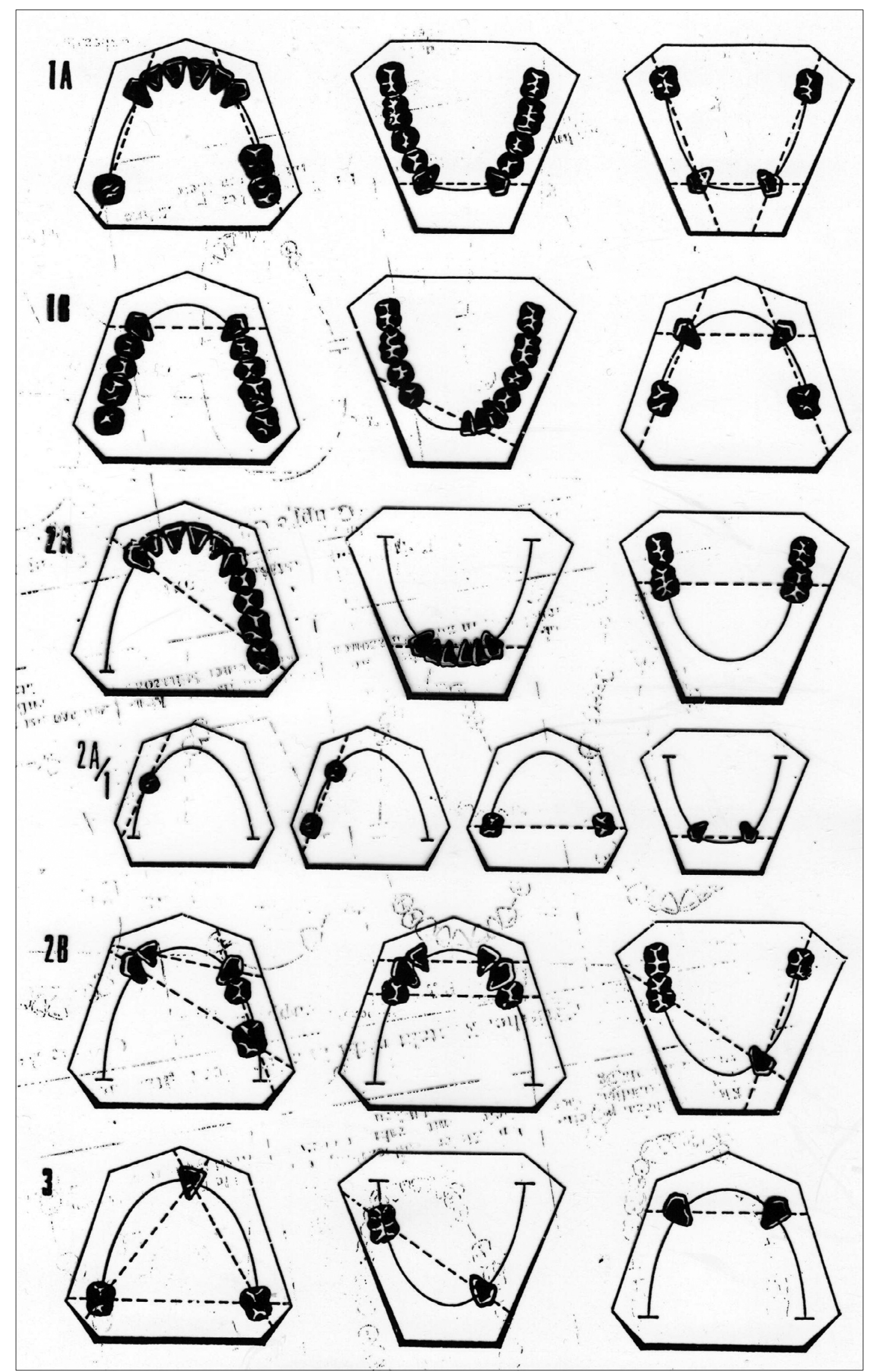

4. ábra: Fábián és Fejérdy féle osztályozási rendszerről készült első fólia 1979-ből (Dr. Fejérdy Pál anyagából) 
Külön említést kell tenni még Eichner féle intermaxilláris osztályozásról, ami egyfajta funkcionális csoportosítás, melynek alapja a támasztózónák száma és eloszlása. Az osztályozás, támasztózónák szerint értékelve a foghiányt, alapot ad a maradék fogazat müködési képességének becslésére. Az Eichner-csoportosításnak három osztálya és tíz alosztálya van. A német nyelvterületen az ő rendszere terjedt el a leginkább.

Eichner a foghiányokat három fő csoportba osztotta, melyeken belül további 3 vagy 4 alcsoportot határozott meg: „A osztály”: az antagonista érintkezések megvannak mind a négy támasztózónában, „B osztály”: nincs (v. nincsenek) meg az antagonista érintkezések mind a négy támasztózónában. B1-ben 3, B2-ben 2, illetve B3-ban 1 támasztózónában, B4-ben pedig csak a frontrégióban van antagonista érintkezés. „C osztály”: nincs antagonista érintkezés egyetlen támasztózónában sem. C/1 csoportban még találhatók fogak mind a két fogívben, $\mathrm{C} / 2$ csoportban már csak az egyik fogívben, míg a C/3 csoport a teljes fogatlanság alosztálya. BlumeGreger tanulmánya szerint a három főcsoport előfordulási gyakorisága a következő: az „A” csoportba az emberek 49,5\%-a, „B” csoportba 22,4\%-a, míg a „C” csoportba 28,1\%-a tartozik.

Eichner úítást hozott a részleges foghiányok osztályozási módjaiba azzal, hogy az általa felállított osztályozási rendszer figyelembe veszi mindkét állcsontban a meglévő természetes fogak számát és topográfiáját, meghatározva így egy intermaxilláris osztályozást. Ezáltal jól mutatja a fogak funkcióképességét, viszont a Fábián- és Fejérdy féle protetikai osztályozással szemben nem ad támpontot a terápiára vonatkozóan (4. ábra).

A részleges foghiányok protetikai klasszifikációjára Magyarországon leginkább a Fábián és Fejérdy által elkészített osztályozás használatos. Ennek alapja a fogpótlások tervezését befolyásoló maradék fogak száma, elhelyezkedésük az állcsonton belül, illetve a készítendő fogpótláson ébredő forgatónyomaték. Az osztályozás segítséget nyújt a felhasználónak a kezelési terv felállítása során, hiszen az egyes osztályoknak és a hozzájuk tartozó alosztályoknak megvan a kezelési terv javaslata, így a beteg vizsgálata során az osztályba sorolást kell helyesen meghatároznia a vizsgálónak és utána a kezelési terv szinte automatikusan adott. Ez nagy segítség a hallgatóknak, nekik nyújt a leginkább mankót a terv készítése során. Általánosságban elmondható, hogy ez az osztályozás a dentális megtámasztást tekinti az elsődleges megvalósítandó követelménynek, a maradék fogazatot ennek szolgálatába kell állítani, és a fogpótlás elkészítése során ezt kell maximálisan szem előtt tartani.

A Fábián és Fejérdy osztályozás szerint a teljesen fogatlan állcsont T osztályba tartozik, míg abban az esetben, amikor az állcsontban nincs hiányzó fog, csak valamely fog felületének kisebb vagy nagyobb destrukciójával, foganyag hiányával állunk szembe, akkor O. osztályról beszélünk.

$A z$ állcsonton belüli részleges foghiány három főosz- tályba (1., 2., 3.), és öt alosztályba (1A, 1B, 2A, 2B, $2 A / 1)$ sorolható. $A z 1$. osztály esetén az állcsontban a maradék fogak száma és elhelyezkedése lehetővé teszi, hogy teljesen dentálisan megtámasztott fogpótlást készítsünk, az így elkészült fogpótlás rágás következtében nem tud elmozdulni egyik irányba sem. 1A alosztályban nem jön létre forgatónyomaték, így végpilléres híd készítése javasolt. Az 1B alosztály esetén forgatónyomaték jön létre, melyet a maradék fogak számának és elhelyezkedésének köszönhetően kompenzálni tudunk oly módon, hogy segédpilléreket vonunk be a híd elhorgonyzásához, így ebben az alosztályban kiterjesztett híd készítése indokolt. 2. osztály esetén a hiányt határoló fogakat összekötő fulcrumvonal körül a fogpótlás egy irányba el tud mozdulni, süllyedni fog. Ebben az esetben nem áll rendelkezésre elég számú fog teljesen dentális megtámasztásra, ezért itt a dentális megtámasztást mukozális megtámasztás egészíti ki. A 2A alosztályban a maradék fogak vagy a fogatlan gerinc egy blokkban helyezkedik el, ez jellemzően egyvagy kétoldali sorvégi foghiány esetén fordul elő.

2B alosztályban a sorvégi és a sorközi foghiány együttesen fordul elő. Mind a 2A, mind pedig a 2B alosztály esetén dento-mukozális megtámasztást tudunk alkalmazni, és a javasolt kezelési terv részleges lemezes vagy kombinált fogpótlás. $2 \mathrm{~A} / 1$ alosztály, subtotális foghiány esetén a maradék fogak száma egy vagy kettő, és itt is a 2. osztálynak megfelelően a fulcrumvonal mentén egy irányba tud süllyedni a fogpótlás. Ebben az alosztályban muko-dentális megtámasztású részleges lemezes fogpótlást vagy teleszkóp elhorgonyzású fogmúvet tudunk készíteni. A 3. osztályban a maradék fogak állcsonton belüli elhelyezkedésének köszönhetően a forgástengely körül mind a két irányba tud sülylyedni a fogpótlás, billegni fog. Ebben az osztályban a 2A/1 alosztályhoz hasonlóan muko-dentális megtámasztású részleges lemezes fogpótlást vagy teleszkóp elhorgonyzású fogmúvet tudunk indikálni annyi különbséggel, hogy itt késleltetett dentális megtámasztást kell alkalmaznunk.

Azok az osztályozási rendszerek, melyek elsősorban az alkalmazott terápia szemszögéből közelítik meg a foghiánytípusok kérdését, számos hátrányos tulajdonsággal rendelkeznek, amiket szintén mérlegelni kell. A legfontosabb változás az utóbbi évtizedek fogpótlásában az enosszeális implantátumok alkalmazása. Az implantátumok használatakor felborul a klasszikus osztályozási forma. Hiba lenne az implantátummal pótolt fogat természetes fogként értékelni az osztályba sorolásnál. Ugyancsak mérlegelendő, hogy valóban szükséges-e az egyes foghiányok pótlása. Számos vizsgálat igazolta, hogy a sorvégi hiányok nem jelentenek feltétlenül rágófunkció csökkenést (megrövidült fogív koncepció).

Az eddigi osztályozási rendszerek hiányosságait, tökéletlenségeit mérlegelve az Amerikai Fogpótlástani Társaság (The American College of Prosthodontists (ACP) korábban a teljes foghiányos állapotok mintájára megalkotott rendszerezést alapul véve, 2002-ben 
publikálta merőben új megközelítésű rendszerét a részleges foghiányos állapotokra. Az osztályozás alapja, hogy megfelelő terápiás irányelveket adjon a gyakorló fogorvos számára, felhasználva napjaink legkorszerübb terápiás lehetőségeit. Négy kategóriát különítenek el az 1. osztálytól a 4. osztályig, ahol az 1 . osztályba tartoznak a legkönnyebben kezelhető esetek, míg a 4. osztályba a legkomplikáltabbak.

Az osztályba sorolás négy kategória alapján történik: 1. a fogatlan állcsont kiterjedése és elhelyezkedése, 2. a pillérfogak állapota, 3. az okklúzió és 4 . a fogatlan gerinc karakterisztikája.

1. A fogatlan állcsont kiterjedése és elhelyezkedése. Súlyossági foka szerint 4 alcsoportot különböztethetünk meg. Ideális vagy kis mértékben nehezített az ellátást, ha a foghiány csak egy állcsontra terjed ki és a következők valamelyike teljesül: frontfoghiány a maxillában, ami két metsző hiányánál nem nagyobb, frontfoghiány a mandibulán, ami a négy metsző hiányánál nem nagyobb, és/vagy bármilyen foghiány bármelyik állcsontban, ami nem nagyobb két premolárisnál vagy egy molárisnál.

Közepesen nehezített az ellátás abban az esetben, ha a foghiány mindkét állcsontra kiterjed és az előzőekben szereplő feltételek valamelyike fennáll, kiegészítve azzal, hogy egyetlen szemfog hiánya esetén is ebbe az alosztályba sorolandó a foghiány.

Alaposan nehezített az ellátás, ha a rágófoghiány bármely állcsonton hosszabb, mint három fog hiánya vagy két molárisé, vagy az elülső és disztális hiányokat együtt értékelve, ha a hiány meghaladja a három fogat.

2. A pillérfogak állapota. Ideálisnak tekinthető a pillérfogak állapota abban az esetben, ha preprotetikai terápiára nincs szükség.

Közepesen rossz a pillérek állapota akkor, ha 1 vagy 2 szextánsban a fogak keményszövetének állapota nem kielégítő intrakoronális (tömés, betét) vagy extrakoronális (rögzített pótlás) viselésére. Szintén ebbe az alosztályba sorolható a pillér akkor, ha 1 vagy 2 szextánsban helyi megtartó kezelés szükséges (pl. parodontológiai, endodonciai).

Nagyon rossz állapotban vannak a pillérek akkor, ha az előbbi megállapítások valamelyike igaz rájuk, de 3 szextánsra kiterjedő az elváltozás. Esetleg komplex megtartó kezelés szükséges.

Kritikus állapotúnak értékeljük a státuszt akkor, ha az előző kritériumoknak megfelelő állapot legalább 4 szextánsra kiterjed, a fogak megtartása kiterjedt és összetett terápiát igényel, vagy a fogak prognózisa kérdéses.

3. Az okklúzió. Ideálisnak tekinthető az okklúzió akkor, ha preprotetikai ellátásra nincs szükség és az állcsontok, valamint a molárisok helyzete Class I. ortodonciai osztályba sorolható.

A közepesen súlyos okklúzió abban különbözik az előző állapottól, hogy az okklúzió helyreállítására esetleg kisebb helyi beavatkozásra van szükség (pl. prematur érintkezés megszüntetése).

Extrém rossznak tekinthető az okklúzió abban az esetben, ha előzetesen nagyobb helyreállításra van szükség, de az okklúzió vertikális dimenziója változatlan marad. Szintén ebbe az alosztályba sorolhatók a II. osztályú moláris vagy állcsonthelyzetek.

Súlyosnak értékeljük az állapotot akkor, ha az okklúzió helyreállítása kiterjedt beavatkozást igényel és a vertikális dimenzióban is történik változás. Szintén ide sorolható a II. osztályú és a III. osztályú moláris vagy állcsonthelyzet.

Mindezeket a besorolási kritériumokat figyelembe véve egy táblázat segítségével az egyes eseteket a négy osztály valamelyikébe sorolhatjuk. (1. táblázat, 5., 6., 7. és 8. ábra)

Az osztályba sorolást segítő táblázat kitöltése egyszerū. Minden osztály és alosztály, a páciensnek megfelelő négyzetébe teszünk jelölést. Amennyiben a páciens értékei több osztályt is érintenek, mindig a magasabb osztályba soroljuk. Fontos ezenkívül figyelembe venni azt is, hogy a tervezett kezelés, vagy protetikai beavatkozás nem befolyásolhatja az osztályba sorolást. Így ezt minden esetben a kezelési terv készítése előtt végezzük. Amennyiben a páciens visel fogpótlást, annak eltávolítása után értékeljük az állapotot. Az 1 . osztályba és a 2. osztályba sorolt betegeket egy osztállyal feljebb helyezzük, ha az esztétikai követelmények fontosak, vagy megvalósításuk nehézségekbe ütközik. Ugyancsak egy osztállyal feljebb soroljuk a pácienst, ha anamnézisében temporomandibuláris diszfunkció (TMD) is szerepel. Amennyiben a páciens felső állcsontja teljesen, és az alsó részlegesen fogatlan, az ismertetettek szerint osztályozzuk a foghiányt. Fordított esetben, ha az alsó állcsont a teljesen fogatlan és vele szemben megtartott fogak találhatók, a páciens automatikusan 4. osztályba sorolandó az eset komplexitása és nehézsége miatt.

\section{Következtetés}

Az irodalomból ismert és világviszonylatban leginkább elterjedt és elfogadott a Kennedy féle osztályozási rendszer, illetve ennek Applegate által módosított formája. Ezek azonban mégsem felelnek meg minden elvárásnak, hiszen nem adnak támpontot a felmerülő terápiás lehetőségekre vonatkozóan, valamint nem tesznek különbséget az alsó és felső fogív között, holott a két fogsor alakja egészen más.

Mindezek alapján a fogpótlástanban elterjedt és használt osztályozási módok közül különös elónyben részesíthetők azok, melyek nem csupán a foghiányok osztályba sorolására törekednek, hanem szem előtt tartják az antagonista viszonyokat is. Ezt a lényeges és fontos szempontot talán egyetlen szerző volt, aki megvalósította: Eichner. Csoportosításának hátránya azonban, hogy nem adott támpontot az adott foghiány terápiás lehetőségeire.

A magyarok munkásságát is megemlítve Lőrinczy és Földvári voltak az első magyar szerzők, akik felismerve az osztályozási módok hiányosságát, javaslatot tettek az adott foghiány terápiájára. 


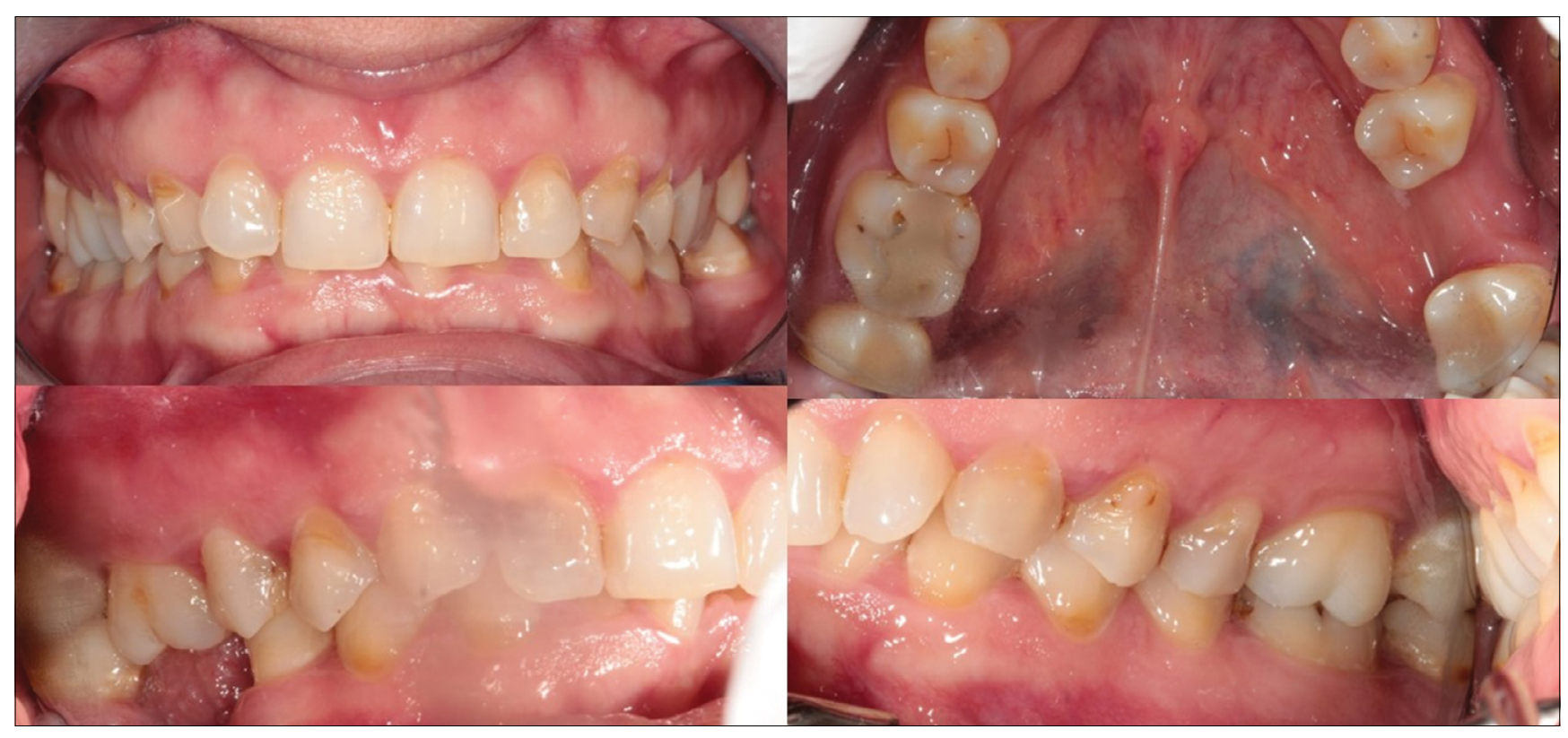

5. ábra: Az ábrán látható páciens a foghiánya alapján ACP I. osztályba sorolható, mert egyetlen foghiánya van 1 szextánsban.

Azonban a mélyharapása miatt már az ACP IV. osztályba kell sorolnunk.

Szintén az ACP IV. osztályba sorolás mellett szól,

hogy az első moláris fogak találkozása sem Class I. osztályú.

Az osztályba sorolást segítő táblázat

\begin{tabular}{|c|c|c|c|c|}
\hline A fogatlan állcsont kiterjedése és elhelyezkedése & $\begin{array}{c}\text { ACP } \\
\text { I. osztály }\end{array}$ & $\begin{array}{c}\text { ACP } \\
\text { II. osztály }\end{array}$ & $\begin{array}{c}\text { ACP } \\
\text { III. osztály }\end{array}$ & $\begin{array}{c}\text { ACP } \\
\text { IV. osztály }\end{array}$ \\
\hline Ideális vagy kis mértékben nehezített ellátás egy állcsonton & & $\geq$ & $8<$ & $4<$ \\
\hline Közepes mértékben nehezített - mindkét állcsont & & & -1 & (2) \\
\hline Nagymértékben nehezített $>3$ fog & & & & 7 \\
\hline Súlyos állapot - kérdéses prognózis & & & & \\
\hline Congenitális vagy szerzett maxillo-faciális defektus & & 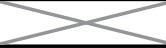 & 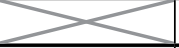 & \\
\hline Pillérfog állapota & & & & \\
\hline Ideális vagy kis mértékben károsodott pillérfog & & & & \\
\hline Közepes mértékben károsodott - 1-2 szextáns & & & & \\
\hline Nagymértékben károsodott - 3 szextáns & & 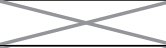 & & 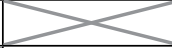 \\
\hline Súlyosan károsodott - 4 vagy több szextáns & 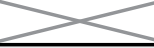 & 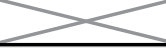 & 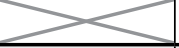 & \\
\hline Okklúzió & & & & \\
\hline Ideális okklúzió & & 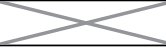 & 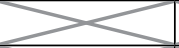 & 3 \\
\hline Közepes mértékben megváltozott okklúzió - helyi kezelés szükséges & & & & \\
\hline Nagymértékben megváltozott okklúzió & & & & \\
\hline Súlyosan megváltozott okklúzió - vertikális magasságváltozás & 3 & 3 & $\Gamma$ & \\
\hline Fogatlan gerinc & & & & \\
\hline 1. osztály & 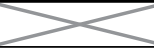 & & & 8 \\
\hline 2. osztály & & & & 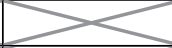 \\
\hline 3. osztály & & & & \\
\hline 4. osztály & 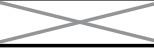 & & & \\
\hline Állapotok, melyek kérdésessé teszik a prognózist & & & & \\
\hline Általános betegség súlyos orális manifesztációja & 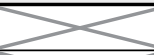 & 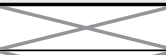 & -1 & \\
\hline Maxillomandibuláris dyskinesia és/vagy ataxia & & & & \\
\hline Nem együttműködő páciens & & & & \\
\hline
\end{tabular}




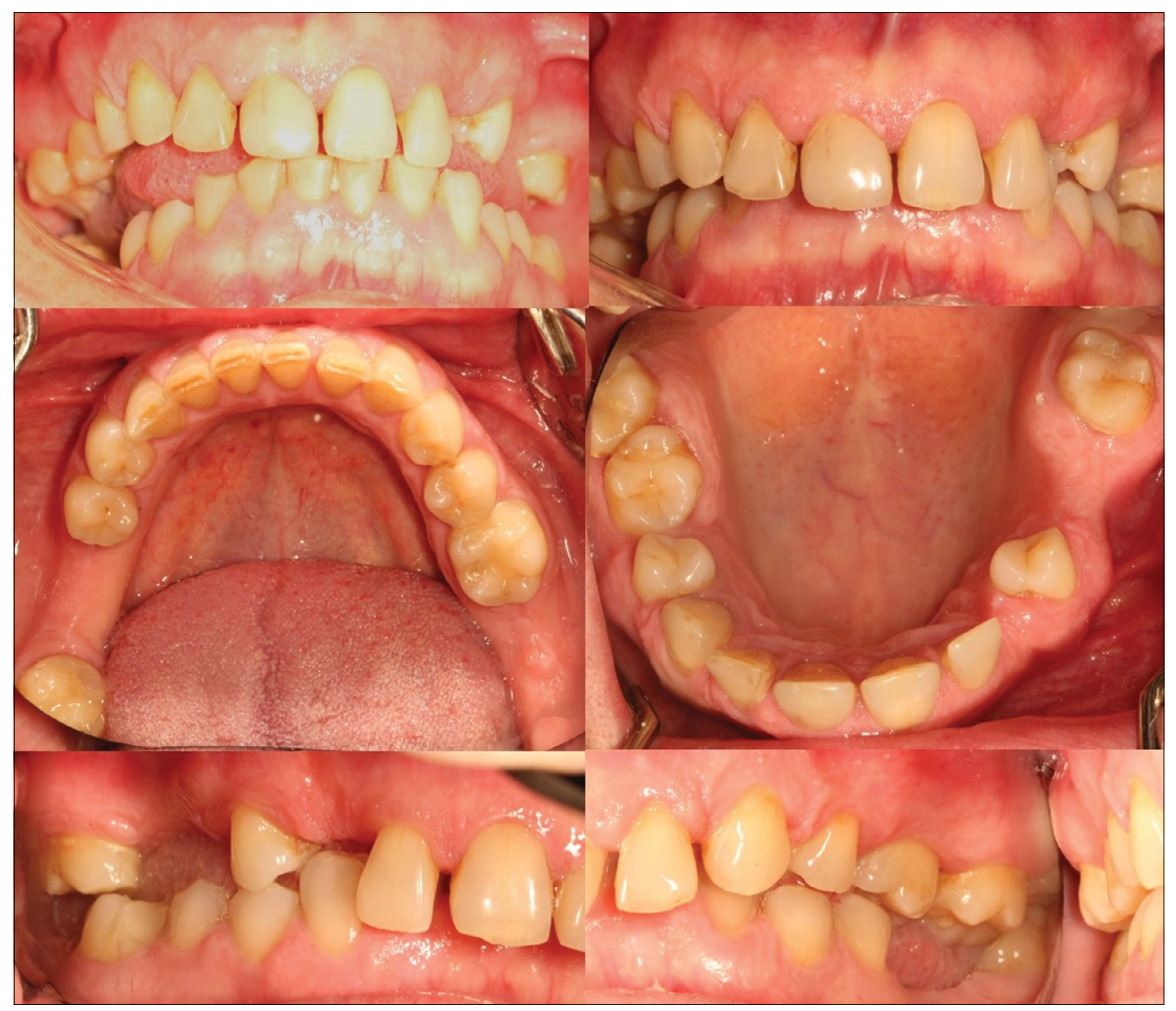

6. ábra: ACP 2. osztályba sorolható a páciens foghiánya alapján, mert két szextánsban is foghiánya van, de eltérő fogívben.

Azonban ebben az esetben is súlyos mélyharapás teszi komplikálttá az ellátást, így ACP IV. osztályba kell sorolnunk a pácienst.

A hazai szerzők két legkiemelkedőbb alakjaként kell említenünk Fábiánt és Fejérdyt, akik felállították a mai magyar fogorvosi gyakorlatban, illetve a protetikai osztályozásban legszélesebb körben alkalmazott besorolást. Ez az osztályba sorolás javaslatot adva meghatározza az adott foghiány terápiájában felmerülő lehetséges konzervatív fogpótlástípusokat.

Az Amerikai Fogpótlástani Társaság által ajánlott osztályozási rendszer magába foglalja az előzőek előnyeit. Ezen túlmenően segít annak eldöntésében is, hogy mely páciensek esetén van szükség komplex, emelt szintű ellátásra, ami magában foglalja akár az implantátum beültetésének lehetőségét is. A rendszer ezeken kívül nagyon jól alkalmazható kutatási, statisztikai és oktatási célokra is. Honosítása és szé- lesebb körben történő elterjedése sok esetben hozzájárulna a páciensek sikeresebb protetikai ellátásához.

A fogászat valamennyi szakterülete folyamatos változáson megy keresztül. A fogpótlástanban a foghiányok és a fogpótlások sokszínúsége egyre összetettebb osztályozási rendszereket vetít előre, amelyeket a fogászati implantátumok egyre nagyobb számú alkalmazása csak tovább bonyolít. A digitális világban talán az is elképzelhető, hogy „algoritmusok” mentén keresünk majd választ kérdéseinkre. De bármennyire is haladunk az automatizmus irányába, a páciensek egyedi igényeinek leginkább megfelelő kezelési terv felállítása még nagyon sokáig a fogorvos feladata lesz, amit a számítógépek nem vehetnek át. 

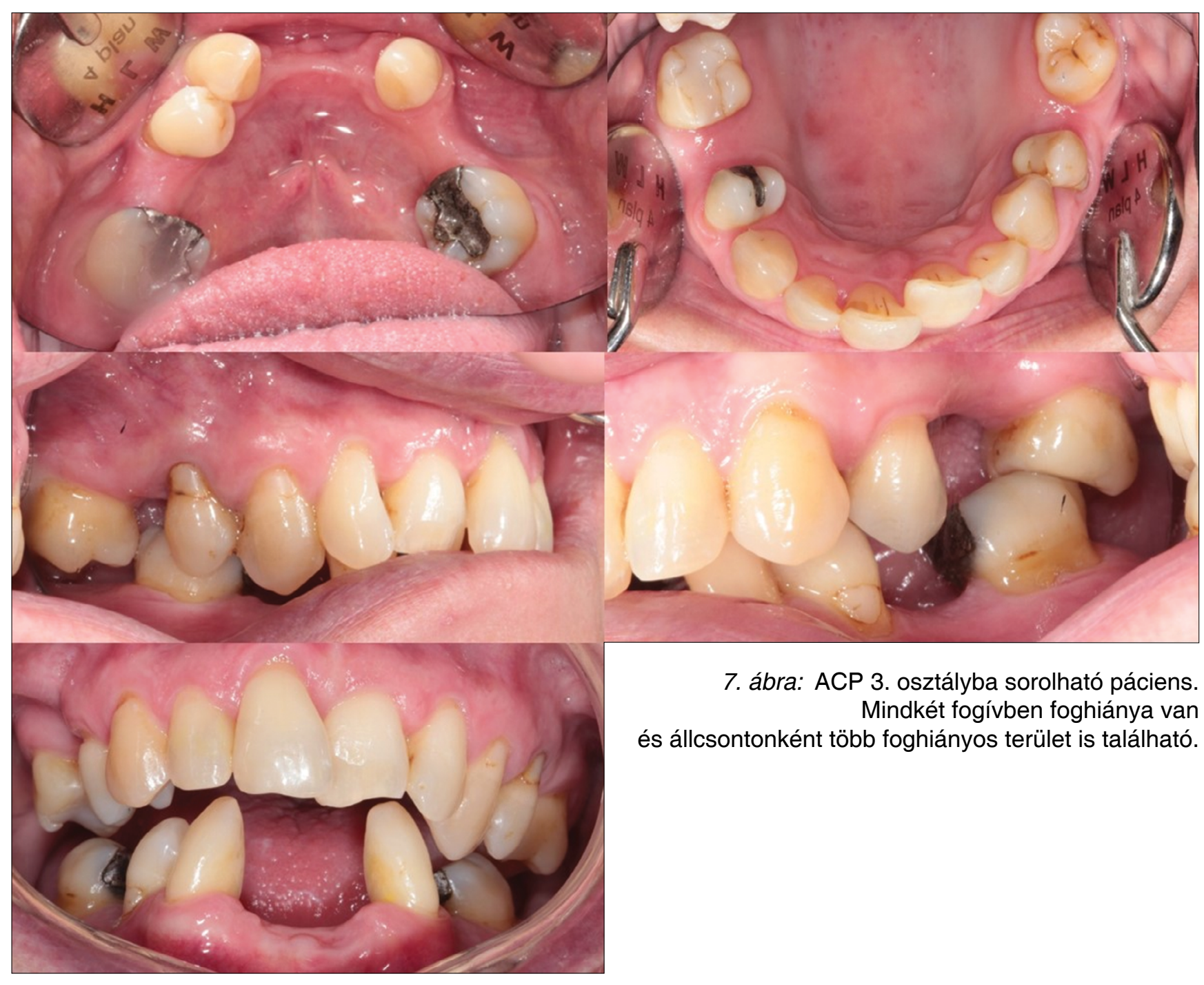

7. ábra: ACP 3. osztályba sorolható páciens. Mindkét fogívben foghiánya van és állcsontonként több foghiányos terület is található.

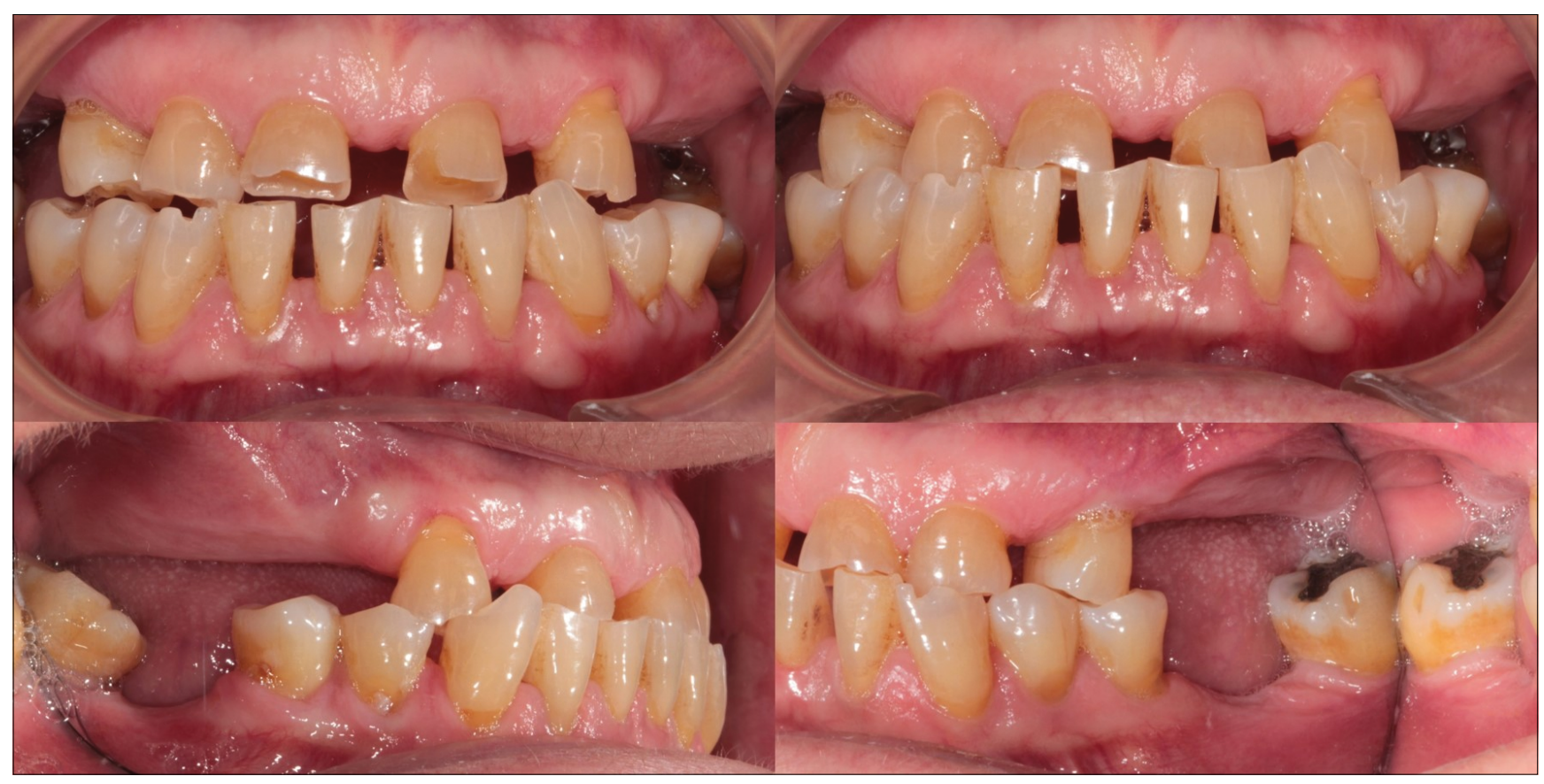

8. ábra: ACP 4. osztályú foghiány. Mindkét állcsonton foghiányos területek találhatók, és a maradék fogak nagymértékü kopásának következtében a harapási magasság erősen megsüllyedt. 


\section{Anyagi támogatás:}

A közlemény megírása, illetve a kapcsolódó kutatómunka anyagi támogatásban nem részesült.

\section{Szerzői munkamegosztás:}

MGy: kézirat megszövegezése

BZ: kézirat szerkesztése

BJ: kézirat megszövegezése, korrekciója

HP: kézirat megszövegezése, korrekciója

$\mathrm{RT}$ : kézirat véleményezése

RM: kézirat megszövegezése, korrekciója

HCs: kézirat ellenőrzése, korrekciója

A cikk végleges változatát valamennyi szerző elolvasta és jóváhagyta.

\section{Irodalom}

1. Applegate OC: An evaluation of the support for the removable partial denture. J Prosthet Dent.1960; 10: 112. https://doi.org/10.1016/ 0022-3913(60)90096-2

2. ARLIN ML: Dental implants and the partially edentulous patient. Diagnosis and treatment planning. Oral Health. 1989; 79: 19-21.

3. Ben-UR Z, Shifman BZ, Aviv I: Further aspects of design for distal extension removable partial dentures based on the Kennedy classification. J Oral Rehabil. 1999; 26: 165-169. https://doi.org/10. 1046/j.1365-2842.1999.00344.x

4. CulpepPer WD, Moulton PS: Considerations in fixed prosthodontics. Dent Clin North Am. 1979; 23: 21-35.

5. DeVAN MM: The nature of the partial denture foundation: Suggestions for its preservation. J Prosthet Dent. 1951; 2: 210-218. https:// doi.org/10.1016/0022-3913(52)90048-6

6. DEVLIN H: Replacement of missing molar teeth. A prosthodontic dilemma. Br Dent J. 1994; 176: 31-33. https://doi.org/10.1038/sj.bdj.4808354

7. Dibal N, Mechanic E: Prosthodontic treatment for the complex mandibular Class I partially edentulous patient. J Dent Que. 1980; 17: 63-65.

8. Goldberg PV: Retention of teeth and placement of implantsin the partially edentulous maxilla: the decision-making process. Dent Implantol Update. 1995; 6: 9-13.

9. IHDE SK: Fixed prosthodontics in skeletal Class III patients with partially edentulous jaws and age-related prognathism: The ba- sal osseointegration procedure. Implant Dent. 1999; 8: 241-246. https://doi.org/10.1097/00008505-199903000-00005

10. KELLY E: Changes caused by a mandibular removable partial denture opposing a maxillary complete denture. J Prosthet Dent. 1972; 27: 140-150. https://doi.org/10.1016/0022-3913(72)90190-4

11. LANEY WR, DESJARDINS RP: Surgical preparation of the partially edentulous patient. Dent Clin North Am. 1973; 17: 611-630.

12. McGarry TJ, Edge MJ, Gillis RE, Hilsen KL, Jones RE, Shipman B, et al: Parameters of Care for the American College of Prosthodontists. J Prosthodont. 1996; 5: 3-71.

13. McGarry TJ, Nimmo A, Skiba JF, Ahlstrom RH, Smith CR, KoumlJAN JH, et al: Classification System for Partial Edentulism. J Prosthodont. 2002 Sep; 11 (3): 181-193. https://doi.org/10.1053/jpro. 2002.126094

14. McGarry TJ, Nimmo A, Skiba JF, et al: Classification system for complete edentulism. J Prosthodont. 1999; 8: 27-39. https://doi. org/10.1111/j.1532-849X.1999.tb00005.x

15. MehtA JD, JogleKAR AP: Vertical jaw relations as a factor in partial dentures. J Prosthet Dent. 1969; 21: 618-625. https://doi.org/10. 1016/0022-3913(69)90009-2

16. MISCH CE, JUDY KW: Classification of partially edentulous arches for implant dentistry. Int J Oral Implantol. 1987; 4: 7-13.

17. PekKarinen V, Yli-Urpo A: Dysfunction of the masticatory system and the mutilated dental arch: Anamnestic index, dysfunction index and occlusal index before restorative and prosthetic treatment. Proc Finn Dent Soc. 1984; 80: 73-79.

18. REYNolds JM: Abutment selection for fixed prosthodontics. $J$ Prosthet Dent. 1968; 19: 483-488. https://doi.org/10.1016/0022-3913 (68) $90064-4$

19. SABRI R: Management of missing maxillary lateral incisors. $J A m$ Dent Assoc. 1999; 130: 80-84. https://doi.org/10.14219/jada. archive.1999.0032

20. Saunders TR, Gillis RE JR, Desjardins RP: The maxillary complete denture opposing the mandibular bilateral distalextension partial denture: Treatment considerations. J Prosthet Den.t 1979; 41: 124-128. https://doi.org/10.1016/0022-3913(79)90292-0

21. TURNer CH, RitCHIE GM: The problems of maxillary complete dentures opposed by retained mandibular incisor and canine teeth (I). Quintessence Int. 1978; 9: 29-34. https://doi.org/10.1016/00167185(78)90022-2

22. WILLARSON KL: Removable partial denture prosthesis for the periodontal patient. The current status-an option. Dent Clin North Am. 1969; 13: 263-279.

23. ZARB GA, MACKAY HF: The partially edentulous patient. I. The biologic price of prosthodontic intervention. Aust Dent J. 1980; 25: 63-68. https://doi.org/10.1111/j.1834-7819.1980.tb03676.x

Marada Gy, Baráth Z, Borbély J, Hermann P, Radics T, Radnai M, Hegedüs Cs

\section{Classification Possibilities of the Partially Edentulous Dental Arches in the Past and Today}

Different classification systems for partial edentulism have been developed to facilitate and standardize prosthetic care. Their basic concepts reflect the up-to-date dental materials and supply policies of the era. The different classification systems had many advantageous properties, but none of them was able to fulfill their requirements.

According to the current approach, the first published classification form was based on the usage of removable partial dentures. Shortly afterwards, Edward Kennedy has created his most commonly used classification system, based on the incidence of individual partial edentulism. A number of excellent dentists have developed a primarily practical-oriented scheme adapted to domestic circumstances, among them the work of Lőrinczy and Földvári, Fábián and Fejérdy should be highlighted.

Considering the weaknesses of the previous systems, the American College of Prosthodontists has developed an entirely new system. Their goal was to provide a therapeutic guideline to the practitioner in accordance with the up-to-date care principles. Depending on the complexity of their care, the classification is based on the characteristics of the ridge, the edentulous area, status of the abutment teeth, and the occlusion.

Keywords: jaw, edentulous, partially, classification 